\title{
Mushroom yields in 10-year-old coppice after spraying with MCPA
}

\author{
MARKKU KIRSI \& PERTTI OINONEN
}

\begin{abstract}
Kirsi, M. \& Oinonen, P. 1981: Mushroom yields in 10-year-old coppice after spraying with MCPA. - Karstenia 21: 1-8.

The mushroom yield in a coppice in Ilomantsi, eastern Finland, was studied during the first three years following aerial MCPA ester spraying. In all three years the yields obtained from the coppice were greater than the yields from the adjacent mixed coniferous forest. MCPA treatment had no acute poisonous effect on the mycoflora but indirectly it caused pronounced changes in the total mushroom yields.
\end{abstract}

Markku Kirsi \& Pertti Oinonen, University of Joensuu, Department of Biology, P.O. Box 111, SF - 80101 Joensuu 10, Finland

\section{Introduction}

Chemical brush control by plane has long been a routine practice in Finnish forestry. Earlier, preparations containing $2,4-\mathrm{D}$ or 2,4,5-T, or mixtures of the two, were used almost exclusively. The public discussion on their possible ecologial drawbacks may have been responsible for the introduction of new arboricides, such as MCPA esters and glyphosate, in chemical coppice treatment in the latter half of the 1970s. No scientific reports exist on the influence of any of these herbicides on the mycoflora and the mushroom yield in coppice areas. In fact, until the last few years research on the subject of mushroom yields in forest sites has been very limited. Recent Finnish investigations have been directed towards elucidating the effect of fertilization on the mushroom yield on peatlands (Veijalainen 1974, Salo 1979) and in heath forests (Ohenoja \& Takkunen 1974, Ohenoja 1978).

This paper reports on mushrooms and mushroom yields in a coppice in llomantsi commune in eastern Finland during the first three years following aerial MCPA iso-octyl ester spraying in 1976. The study is a part of a larger project of the Department of Chemistry and Biology, University of Joensuu, which deals with the ecological consequences of aerial arboricide treatment in a developing forest ecosystem (Tahvanainen 1980). The project was supported by grants from the Academy of Finland.

\section{Materials and methods}

\section{A. Study area}

The investigation was carried out during 1977-1979 in Ilomantsi, in the village of Lemivaara $\left(62^{\circ} 50^{\circ} \mathrm{N}\right.$, $30^{\circ} 56^{\prime} \mathrm{E}$ ) in eastern Finland.

The original Vaccinium type (VT) forest of the experimental site had been clear-cut in 1968. Shallow patches, about 2500 per hectare, were dug in 1969 and the area was sowed with pine (Pinus sylvestris) seeds in the same year. By the spraying year, 1976, the study area was covered by a dense bush layer of pine, about 2.0-2.5 $\mathrm{m}$ in height, and birch (Betula pubescens and B. pendula) and aspen (Populus tremula), about $2.5 \mathrm{~m}$ in height, with some rowan (Sorbus aucuparia), willows (Salix spp.), juniper (Juniperus communis) and small spruce (Picea abies). The main dwarf shrubs were Calluna vulgaris and Vaccinium vitis-idaea, with some Empetrum nigrum. Herbs were abundant, the dominant species being, Deschampsia flexuosa, Epilobium angustifolium, Deschampsia cespitosa and Calamagrostis epigejos. There were a few mosses (mainly Polytrichum commune and Pleurozium schreberi) and very sparse lichen vegetation. The ground of the study area is flat. The soil is a typical podsol with an A-horizon of about $5 \mathrm{~cm}$ and B-horizon of about $10-15 \mathrm{~cm}$.

The experimental site of $200 \times 450 \mathrm{~m}$ was divided into three $200 \times 150 \mathrm{~m}$ sectors, each sector was further divided into three $200 \times 50 \mathrm{~m}$ strips (Fig. 1). The central strip of each sector was sprayed with 
arboricide, one strip was left as a control and on the third strip mechanical coppice treatment was carried out, to produce a mixed pine-birch stand, within a 60 $m$ belt at the NE end of the strip.

The brush spraying treatment was carried out on August 10, 1976 by plane. The commercial preparation used (Brush Killer, Kemira Oy) contained the iso-octyl ester of 4-chloro-2-methyl phenoxyacetic acid (MCPA) at a concentration of $500 \mathrm{~g} / 1$. The rate of application was $5 \mathrm{~kg}$ of the preparation in 451 of water per hectare.

\section{B. Effect of MCPA treatment on vegetation}

The MCPA iso-octyl ester preparation affected the trees most strongly. About $80-100 \%$ of the deciduous bushes were dead in the following spring and after-sprouting was minimal. Most of the surviving birches and aspens were situated at the margins of the treated strips. The pines were damaged, too. In spring 1977 only one pine in two had a living leader and some of the smallest pines were completely dead. The pine injuries were partly due to pine-twisting rust (Melampsora pinitorqua), which had a mass occurrence in 1976. On the untreated strips, about $20 \%$ of the pines hade dead leaders, apparently due to the rust. In the field layer the most severely injured species were Calluna vulgaris and Vaccinium vitis-idaea; about $50 \%$ of their shoots died in consequence of the treatment. Calluna vulgaris recovered rapidly, however. By summer 1979 it had almost reached its original coverage and biomass in the experimental area (Lehikoinen 1980). Vaccinium vitis-idaea recovered much more slowly. The MCPA treatment had a minor effect on

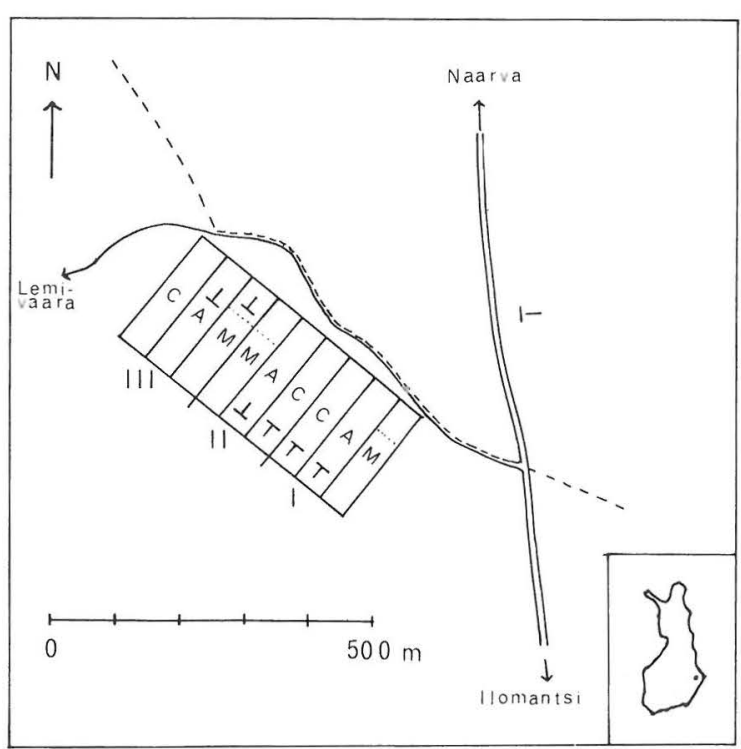

Fig. 1. The study area at Lemivaara in Ilomantsi, eastern Finland. The area has been divided into three sectors (I, II, III), each sector has a central MCPA-treated strip (A), a control strip $(C)$, and mechanically coppice-treated strip (M). The sample plots are shown by bars. the other field layer species and no changes at all were observed in the ground layer.

\section{Sample plots and sampling methods}

Eight sample plots of $50 \mathrm{~m}^{2}(2 \times 25 \mathrm{~m})$ were set up in 1977 in sectors I and II; four plots on the MCPAtreated strips and and four on the control strips (Fig. 1). In 1978 four further plots were set up on sector III, to give a total experimental area of $600 \mathrm{~m}^{2}$. Each strip had two experimental plots perpendicular to each other. This guaranteed that the minor features of the sites were included in the sample plots among other things the bottoms of the ditches were represented in the longitudinal plots.

All the mushroom fruit bodies were collected from each plot at 10-20 day intervals during the snow-free period (from the end of May to late September early November) in 1977-1979. The fruit bodies were sorted by species, counted and weighed at Joensuu University within one or two days of sampling. The dry weights were recorded after drying at $80^{\circ} \mathrm{C}$ for 24 hours in 1977 and at $60^{\circ} \mathrm{C}$ for about 48 hours in $1978-1979$. The species were identified by the authors on fresh material. Some of the dried specimens were determind by Miss Heli Heikkilä, Lic. Phil. (Kuopio Museum). Some of the fungi were identified only to the genus and the determinations may be slightly unreliable in certain cases. Specimens of the uncertain groups are preserved at the University of Joensuu.

\section{Mushroom species}

The mushroom species found on the sample plots during the growing seasons 1977-1979 have been listed in Table 1. The MCPA treatment had no fundamental effect on the total numbers of the fungal species. In 1977 and 1979 the chemically treated areas had 3-4 species fewer than the control areas but in 1978 they had 5 species more. About half of the c. 120 taxa occurred almost equally abundantly in the arboricide-treated plots and the untreated plots. Of the species restricted to the treated or untreated sample plots, most were found in a single plot, so that their occurrence may clearly be explained by chance. Among the most frequent species (growing on at least two strips), only Lactarius vietus and Leccinum scabrum were limited to the control plots, and Gyromitra infula was the only species growing merely in the MCPA-treated plots. Species clearly occurring more abundantly on the arboricide-treated than on the untreated areas were Lactarius helvus, Omphalina spp. and Inocybe 
Table 1. Dry weight $(\mathrm{g} / \mathrm{ha}$ ) of the fungi collected in $1977-1979$ in a coppice in Ilomantsi after aerial MCPA spraying; $\mathrm{A}=$ arboricide-treated, $\mathrm{C}=$ control, $\mathrm{M}=$ mechanically coppice-treated.

\begin{tabular}{|c|c|c|c|c|c|c|c|c|}
\hline & \multicolumn{2}{|c|}{1977} & \multicolumn{2}{|c|}{1978} & \multirow[b]{2}{*}{ M } & \multicolumn{3}{|c|}{1979} \\
\hline & A & $\mathrm{C}$ & A & $\mathrm{C}$ & & A & C & M \\
\hline Aleuria aurantia & 1 & & & & & & & \\
\hline Gyromitra infula & 93 & & 55 & & & 50 & & \\
\hline Peziza badia & & & 5 & & & 74 & & \\
\hline Peziza sp. & & & 2 & 10 & & & & \\
\hline Cudonia confusa & & & 12 & 2 & & 25 & & \\
\hline C. circinans & & & 1 & & & & & \\
\hline Calocera viscosa & & & 7 & & & 7 & 1 & \\
\hline Dacrymyces sp. & & & 4 & & & & & \\
\hline Thelephora terrestris & 1918 & 1056 & 1760 & 620 & 5617 & 208 & & 73 \\
\hline Merulius tremellosus & 65 & & & & & & & \\
\hline Coltricia perennis & 200 & 25 & 252 & 111 & & 148 & 151 & \\
\hline Gloeophyllum sepiarium & 150 & 47 & 19 & 12 & & & 48 & \\
\hline Hirschioporus abietinus & & & & 238 & & & & \\
\hline Polyporus brumalis & & & & & & & & 328 \\
\hline$P$. ciliatus & 1 & & & & & 59 & 5 & \\
\hline P. melanopus & & & & & & 15 & & \\
\hline Tyromyces sp. & & & 41 & & & & & \\
\hline Leccinum scabrum & & & & 427 & 6160 & & 3053 & 3735 \\
\hline L. variicolor & & 252 & & & & & & \\
\hline L. vulpinum & & & 173 & & & & & \\
\hline Suillus bovinus & & 68 & 35 & 1152 & 23 & 807 & 126 & \\
\hline S. luteus & & & & 89 & & 38 & 210 & \\
\hline S. variegatus & 1045 & 1008 & 579 & 4832 & 775 & 240 & 1192 & \\
\hline Xerocomus subtomentosus & & & & & & 113 & & \\
\hline Lactarius helvus & 838 & & 573 & 160 & & 666 & 452 & \\
\hline L. mammosus & 18 & & & & & 10 & & \\
\hline L. torminosus & & & & & & & 200 & \\
\hline L. vietus & & 342 & & 505 & 69 & & 1200 & 167 \\
\hline Russula aeruginea & 58 & & & & & & & \\
\hline$R$. emetica & & & & & & & 21 & \\
\hline R. fragilis & & & & & & 18 & & \\
\hline R. puellaris & & & & 93 & & & & \\
\hline R. xerampelina & & & & & & & 47 & \\
\hline Russula spp. & & 171 & & 17 & & 147 & & \\
\hline Paxillus involutus & 685 & 182 & 675 & & 3770 & 858 & & 7560 \\
\hline P. atromentosus & & & & & & 48 & & \\
\hline Hygrophoropsis aurantiaca & 6 & 3 & & & & & 15 & \\
\hline Gomphidius roseus & & 111 & 39 & 95 & & 217 & 246 & \\
\hline Chroogomphus rutilus & & 42 & 9 & 88 & & 5 & 259 & \\
\hline Hygrophorus olivaceoalbus & & & & 15 & & & & \\
\hline Hygrophorus sp. & & 16 & & & & & & \\
\hline Amanita fulva & & 24 & & & & & 380 & \\
\hline A. lividopallescens & & & & 25 & & & & \\
\hline A. muscaria & & & & 424 & & & & \\
\hline A. porphyria & & 11 & & & & 88 & 12 & \\
\hline A. vaginata & & & & & & & 384 & \\
\hline Lentinellus omphalodes & & 8 & & & & & & \\
\hline Lentinellus sp. & & & & & & & 3 & \\
\hline Lentinus lepideus & & & & & 200 & 99 & & \\
\hline Panellus serotinus & & 187 & 79 & 567 & & 223 & 586 & \\
\hline Cantharellula umbonata & 351 & 208 & 297 & 183 & 13 & 386 & 282 & 96 \\
\hline Clitocybe clavipes & 206 & 72 & & & & & & \\
\hline C. gibba & 19 & & & & & & & \\
\hline Clitocybe sp. & 71 & 6 & 31 & 30 & & 47 & 15 & 6 \\
\hline Mycena epipterygia & 94 & 51 & 13 & 16 & 6 & 83 & 34 & \\
\hline M. galericulata & & & 144 & & & & & \\
\hline M. galopus & & & & & & & 1 & \\
\hline M. laevigata & & & & & & 4 & & \\
\hline Mycena spp. & 13 & 4 & 16 & 3 & 1 & 11 & 38 & 1 \\
\hline Hemimycena sp. & 5 & & & & & & & \\
\hline
\end{tabular}


Table 1 (contd.).

\begin{tabular}{|c|c|c|c|c|c|c|c|c|}
\hline & \multicolumn{2}{|c|}{1977} & \multicolumn{3}{|c|}{1978} & \multicolumn{3}{|c|}{1979} \\
\hline & A & $\mathrm{C}$ & A & $\mathrm{C}$ & M & A & $\mathrm{C}$ & $\mathrm{M}$ \\
\hline Marasmius androsaceus & + & & 2 & 1 & & 19 & 1 & 1 \\
\hline Marasmius sp. & 1 & & + & & & & & 2 \\
\hline Omphalina ericetorum & & & 3 & & & & & \\
\hline O. sphagnicola & & & & & & 8 & & \\
\hline Omphalina spp. & 9 & 1 & 9 & 1 & & 15 & & 2 \\
\hline Xeromphalina campanella & & 41 & 1 & 3 & & & & \\
\hline$X$. caulinalis & & & & & & 5 & & \\
\hline Cystoderma amianthinum & 47 & 17 & 51 & 39 & 3 & 50 & 15 & 9 \\
\hline C. granulosum & 17 & 22 & 5 & & 33 & & & \\
\hline Laccaria laccata & 367 & 85 & 116 & 13 & 588 & 163 & & 357 \\
\hline Oudemansiella platyphylla & 627 & & 123 & & & 49 & 199 & \\
\hline Collybia acervata & & & & & & & & 488 \\
\hline C. asema & & & 6 & & 667 & 53 & & 512 \\
\hline C. butyracea & & & & & 425 & & & 372 \\
\hline C. cookei & & 8 & & & & & & \\
\hline C. cirrhata & 5 & + & 2 & 2 & 11 & 1 & & 1 \\
\hline C. dryophila & & 6 & 5 & & & & & \\
\hline C. succinea & & & 3 & & & 3 & & \\
\hline Collybia sp. & & & 33 & & & & 1 & \\
\hline Armillariella mellea & 367 & 164 & 111 & 935 & & 78 & 1148 & \\
\hline L.yophyllum sp. & 15 & & 67 & 17 & 12 & & & \\
\hline Tephrocybe sp. & & & & & & 21 & & \\
\hline Tricholoma album & & & & & & 7 & 7 & \\
\hline T. flavobrunneum & & & & & & 56 & & \\
\hline Pluteus atricapillus & & & & & & 24 & & \\
\hline Pluteus sp. & 19 & & & & & & 93 & \\
\hline Rhodophyllus sp. & 25 & 60 & 15 & 33 & & 5 & 6 & 16 \\
\hline Rhodocybe sp. & & 2 & & & & & & \\
\hline Stropharia hornemannii & 494 & 943 & 260 & 1174 & & 1903 & 81 & \\
\hline Psilocybe rhombispora & & & & & & & & 1 \\
\hline Psilocybe sp. & & & 1 & & & & & \\
\hline Kuehneromyces mutabilis & & 343 & & 2450 & & 6 & 290 & \\
\hline Naernatoloma capnoides & 759 & 211 & 1230 & 619 & 2536 & 906 & 590 & 1308 \\
\hline N. polytrichii & 29 & 15 & 8 & 4 & & & & 5 \\
\hline Psathyrella sp. & 11 & & 13 & & 21 & 1 & & 13 \\
\hline Pholiota lubrica & & & & & & & & 10 \\
\hline Pholiota sp. & 5 & & 53 & 10 & & & & \\
\hline Dermocybe cinnamomeobadia & & 77 & & & & & & \\
\hline D. cinnamomeolutea & 47 & 14 & 76 & 372 & 78 & 383 & 1171 & 74 \\
\hline D. semisanguinea & 43 & & 22 & & 146 & 231 & & 121 \\
\hline Dermocybe sp. & & & & & & & 3 & \\
\hline Cortinarius anomalus & & & & & & 16 & & 476 \\
\hline C. gentilis & & 4 & & & & & & \\
\hline Cortinarius spp. & 48 & 46 & 34 & 886 & 1506 & 130 & 970 & 495 \\
\hline Galerina hypnorum iıll. & 32 & 25 & 11 & 16 & 8 & 49 & 34 & 3 \\
\hline G. marginata & & & 24 & & & 5 & 5 & \\
\hline Galerina sp. & 12 & 17 & 17 & 8 & 22 & 14 & 7 & 3 \\
\hline Gymnopilus penetrans & & 39 & & & & 243 & 17 & 123 \\
\hline Gymnopilus sp & 188 & 12 & 88 & 29 & 52 & 35 & & \\
\hline Inocybe fastigiata & & & & & & 33 & & \\
\hline Inocybe spp. & 174 & 48 & 124 & 76 & & 182 & 23 & 66 \\
\hline Hebeloma mesophaceum & & & & & & & & 50 \\
\hline Hebeloma sp. & & & 3 & & & 5 & & 2 \\
\hline Agaricales spp. & + & 9 & 21 & & 2 & 9 & 9 & 2 \\
\hline Lycoperdon foetidum & & & & & & 5 & & \\
\hline L. perlatum & & & 52 & 11 & & 1 & & \\
\hline Lycoperdon sp. & 18 & 18 & & 12 & & & & \\
\hline
\end{tabular}


spp. Species more abundant on the untreated areas were Russula spp., Chroogomphus rutilus and Cortinarius spp.

Since Lactarius vietus and Leccinum scabrum occur together with birch, their absence from the arboricide-treated sites was to be expected. The reason why those three taxa were more numerous at the untreated sites is not clear. Chroogomphus rutilus is a mycorrhizal fungus of pine and should have occurred in both treated and untreated plots. The fruit bodies of Cortinarius and Russula were not always identified to species. These two genera include mycorrhizal species of both conifers and broadleaved trees, and the species differ greatly in their ecological requirements. Thus, the reason for their greater abudance in the control plots is uncertain.

All the species gaining an advantage from the chemical brush treatment were those which prefer soils free of vegetation. The sparse and patchy or completely dead field layer vegetation in the treated plots explains the distribution of these species.

\section{Effect on mushroom yield}

\section{A. Total mushroom yield}

The total mushroom yields per hectare in the study area were $92.9 \mathrm{~kg}$ in $1977,158.2 \mathrm{~kg}$ in 1978 and 140.5 $\mathrm{kg}$ in 1979. In the uncut mixed coniferous forest 500 $\mathrm{m}$ northeast of the experimental area (Fig. 1) the corresponding values, estimated in two experimental plots of $50 \mathrm{~m}^{2}$, were $81.9 \mathrm{~kg}, 50.3 \mathrm{~kg}$ and $133.4 \mathrm{~kg}$. The total yield per hectare in the study area was thus of the same order of magnitude as in the forest in two of the years, and in 1978 it was three times as great, apparently due to the poor yield of Russulas in the forest.

In the MCPA-treated plots the total mushroom yields per hectare in the three study years were 96.7 $\mathrm{kg}, 74.2 \mathrm{~kg}$ and $122.6 \mathrm{~kg}$. In the plots not treated with arboricide, the corresponding figures were 83.9 , 242.2 and $158.3 \mathrm{~kg}$. In 1977 the abundance of mushrooms was distinctly greater in the sprayed than in the control plots. In 1978 the yields were much larger on unsprayed strips in all three sectors than on the MCPA-sprayed strips (Fig. 2). In 1979 also, the yields were larger on the unsprayed strips, but the differences between the strips were less distinct.

The annual fluctuation in the mushroom yields was greatest on the unsprayed strips. The new sampling plots on sector III included in the sampling program in 1978 had higher yields than the plots on sectors I and II, and their inclusion resulted in an apparent increase in the annual fluctuation. However, it can be seen in Fig. 2 that the mushroom yields obtained in the unsprayed strips in 1978 were two- or threefold those of 1977 on sectors I and II, as well.

\section{B. Yield of commercial mushrooms}

Eight species of commercial mushrooms occurred in the study area. (The commercial mushrooms in Finland consist of 30 species recommended in 1971 by the Committee on the Economic Utilization of Mushrooms as being easily identified edible mushrooms with good flavour and productivity.) Of these Suillus bovinus, S. variegatus, Armillariella mellea, Kuehneromyces mutablis and Naematoloma capnoides produced fruit bodies every year. In 1977 Suillus bovinus occurred only in the control plots; in 1978 it was very abundant in the control plots and occurred in small quantity in the sprayed plots, too, but in 1979 its abundance was significantly greater in the MCPA-treated than in the untreated plots. $S$. variegatus had the largest yield among the commercial mushrooms. In 1977 it was equally abundant on the treated and control plots, after which its yield was poorer on the sprayed areas than that on the control areas. The yield of Armillariella mellea had the same pattern, but no distinct trends

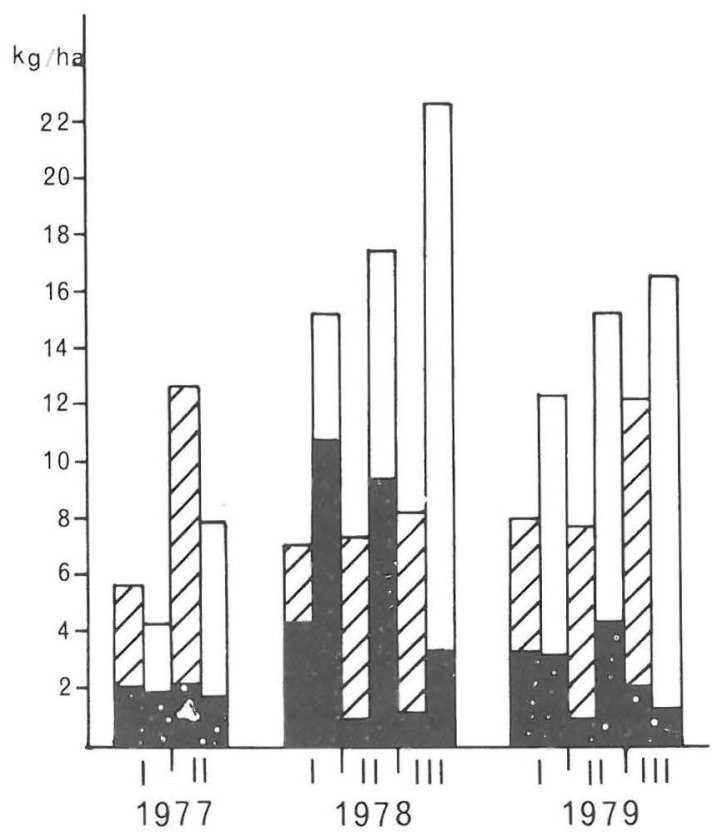

Fig. 2. Mushroom yields (dry wt, $\mathrm{kg} / \mathrm{ha}$ ) on the MCPAtreated and control strips in $1977-1979 . \mathrm{I}, \mathrm{II}, \mathrm{III}$, = sector number; hatched = MCPA-treated strip; shaded = commercial mushrooms. 
were observed in the yield of Naematoloma capnoides. Kuehneromyces mutabilis was too rare to allow any conclusions about the effect of MCPA treatment on this fungus. The same was true of the other commercial mushrooms found in the study area, viz. Suillus luteus, Leccinum vulpinum and Lactarius torminosus.

The annual and spatial fluctuation in the yield of the commercial mushrooms was fairly pronounced (Fig. 2). The proportion of commercial mushrooms was largest in 1978 on sector II, where they amounted to $70 \%$ of the total yield. The smallest yields of commercial mushrooms $(0.8-0.9 \mathrm{~kg}$ dry wt/ha) were obtained in 1978 and 1979 on the sprayed strips of sector II, and their proportion was lowest on the coppiced strip of sector III $(7.9 \%)$. The difference between the MCPA-sprayed and unsprayed areas was most pronounced in 1978, when the yield of the commercial mushrooms on the control strips was $1.6-8.7$-fold the yield on the sprayed strips. In 1977 there were no differences and in 1979 the difference was notable only on sector II.

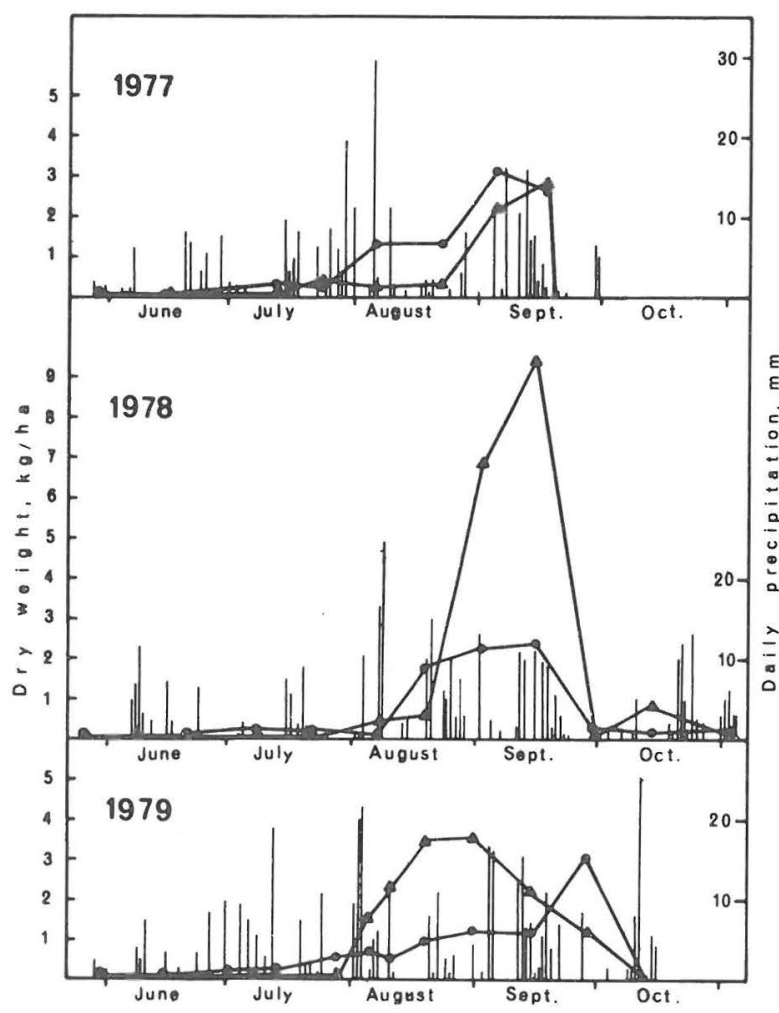

Fig. 3. Seasonal fluctuations in mushroom yields (dry wt, $\mathrm{kg} / \mathrm{ha}$ ) in 1977-1979 and mean daily precipitation (mm) at the meteorological station of Ilomantsi $(18 \mathrm{~km} \mathrm{~S}$ of the study area); $\longrightarrow$ yield from MCPA-treated plots, yield from control plots.

\section{Seasonal pattern of mushroom yields}

The weather conditions at the nearest meteorological station, at Ilomantsi village $\left(62^{\circ} 41^{\prime} \mathrm{N}, 30^{\circ} 57^{\prime} \mathrm{E}\right)$, are shown in Table 2, and the seasonal pattern of the mushroom yields is illustrated in Fig. 3 .

Table 2. Mean temperatures $\left({ }^{\circ} \mathrm{C}\right)$ and precipitation $(\mathrm{mm})$ in May-November at the meteorological station of Ilomantsi in $1977-1979$.

\begin{tabular}{lcrrrrrr}
\multicolumn{8}{c}{ Month } \\
Year & V & VI & VII & VIII & IX & X & XI \\
\multicolumn{7}{c}{ Mean temperature } \\
1977 & 8.4 & 13.5 & 15.6 & 13.1 & 4.3 & 0.8 & -2.1 \\
1978 & 8.6 & 12.8 & 15.0 & 11.8 & 7.0 & 0.9 & -1.5 \\
1979 & 10.2 & 14.0 & 15.2 & 14.4 & 7.7 & 0.7 & -1.4 \\
$1930-1961$ & 7.3 & 13.1 & 16.0 & 14.1 & 8.3 & 2.1 & -2.7 \\
1977 & Precipitation & & & & & \\
1978 & 62 & 42 & 83 & 73 & 91 & 70 & 81 \\
1979 & 2 & 45 & 34 & 112 & 80 & 63 & 75 \\
$1930-1961$ & 60 & 43 & 73 & 108 & 120 & 62 & 82 \\
& 37 & 62 & 79 & 75 & 70 & 64 & 49
\end{tabular}

In 1977 and 1979 the amounts of mushrooms began to increase at the beginning of August. In 1978 the rather low precipitation during spring and midsummer delayed the beginning of the mushroom season but the plentiful rains in August and the first half of September caused peak yields in the second half of August and in September. The end of the mushroom season was mainly determined by the snow. In 1977 the first snow came on September 20 but it melted soon and the mean daily temperatures rose above $0^{\circ} \mathrm{C}$ for a couple of days, probably allowing the development of some new fruit bodies. As these were not collected, the total mushroom yield for 1977 may have been a little higher than reported here. In 1978 night frosts were common after September 24, resulting in an abrupt decrease in mushroom abundance. In spite of the frequent night frosts, the mushroom season continued at a low level (mainly Thelephora terrestris, Naematoloma capnoides, Panellus serotinus and small-sized saprophytic species) until it was terminated by the establishment of a permanent snow cover in midNovember. In 1979 the mean daily temperature remained below zero after October 22, but the mushroom season had been ended a week earlier by an ample fall of snow.

The differences in mushroom yields between the MCPA-treated and control plots were immaterial in the middle of the summer, when the total yields were low. In August 1977 the sprayed areas had 
significantly more fruit bodies than the unsprayed areas, $2745 \mathrm{~g}$ dry wt/ha versus $550 \mathrm{~g} / \mathrm{ha}$. The species mainly responsible were Thelephora terrestris, Suillus variegatus, Oudemansiella platyphylla and Lactarius helvus. The difference became smaller later on and had disappeared by the last collecting day, September 19. In 1978 the relations between the mushroom yields from the treated and control plots were the same as in 1977 up to mid-August. In September the yield in the control plots was exceptionally high but that of MCPA-treated plots kept at the same level as in the previous year. The mushrooms chiefly contributing to the superiority of the yields from the control areas were Suillus variegatus, Leccinum scabrum, Kuehneromyces mutabilis, Thelephora terrestris, Stropharia hornemannii, Suillus bovinus and Armillariella mellea. The species responsible for the small October peak in the control areas were Thelephora terrestris, Panellus serotinus, Hirschioporus abietinus and Naematoloma capnoides.

In 1979 the control areas were superior to the sprayed areas from the beginning of August up to mid-September, the species with the highest yields in the control plots being Leccinum scabrum, Paxillus involutus, Lactarius vietus, Suillus variegatus and Armillariella mellea. During the second half of September the sprayed areas were clearly more productive. The difference was almost exclusively due to the abundant occurrence of Stropharia hornemannii in one sprayed plot.

\section{Discussion}

The mushroom yields obtained from the coppice at Lemivaara $(93-158 \mathrm{~kg} / \mathrm{ha})$ were greater than the yields from the adjacent mixed coniferous forest and quite comparable to the yields reported for pine forests on other parts of Finland. Rautavaara (1947) has estimated that in Finland the average mushroom yields in pine forests are $72-114 \mathrm{~kg} / \mathrm{ha}$ and in mixed spruce forests $90-150 \mathrm{~kg} / \mathrm{ha}$. According to the estimates of Ohenoja (1978), in Muhos in 1973-1975 the mushroom yields ranged from a few kilograms to over $300 \mathrm{~kg}$ per hectare, being more often below than above $100 \mathrm{~kg} / \mathrm{ha}$. The mushroom yields on the brush area at Lemivaara correspond well with these figures. One reason why the coppice had greater yields than the adjacent forest is that its mycoflora was more varied. The number of tree species is higher in coppice than in closed forest, allowing the occurrence of many species of mycorrhizal fungi. The stumps and logging residue provide ample substrates for wood-rotting saprophytic fungi, and the network of ditches creates a variety of microhabitats in the otherwise uniform terrain.

The influence of the MCPA iso-octyl ester treatment on the species composition of the mushrooms was insignificant. Clear differences between the chemically treated and untreated areas were few, and some of them were probably due to the patchy distribution of the fruit bodies. Estimation of the effect of external factors on the frequency of the fungal species is complicated by the uneven distribution and the large annual fluctuation in the amounts of fruit bodies at the same site. But the results show clearly that the MCPA coppice treatment has no acute poisonous effect on the mycoflora. The total numbers of mushroom species were similar at the treated and untreated sites and the greater part of the most frequent species occurred in both the control and treated plots. This result is not particularly surprising. Applications of herbicides at normal field rates have not been reported to cause changes in the total numbers of soil microorganisms or in the gross microbial activity (Audus 1964, Bollen 1961). Despite the numerous reports of inhibition of fungal growth by synthetic auxins, including MCPA esters (Gruen 1959), there seems to be no reason to suppose that auxins are active growth regulators in fungi (Burnett 1976). MCPA seems to be less fungitoxic than some other herbicides (Wilkinson \& Lucas 1969). Although growth was depressed, most of the saprophytic soil fungi tested by Wilkinson and Lucas were able to grow in media containing up to $1000 \mathrm{ppm}$ MCPA. Sixteen days after the spraying in Ilomantsi the concentrations of MCPA residues were $239 \mathrm{ppm}$ dry wt in birch twigs, $37 \mathrm{ppm}$ in moss and 0.1-4 ppm in the soil (Eronen et al. 1979). In the following year (1977) the figures for birch twigs, moss and soil were $44-76 \mathrm{ppm}, 0 \mathrm{ppm}$ and $0-0.7 \mathrm{ppm}$, respectively. The residues in fungi were low: in a sample of Suillus luteus taken six weeks after the treatment the MCPA concentration was below 0.1 ppm (Eronen et. al. 1980).

These figures suggest that the toxic effect of MCPA treatment on the mycoflora cannot be significat. In contrast to the negligible effect of MCPA treatment on the occurrence of single species, its effect on the mushroom yields was pronounced. This was due to the numerous changes in the brush ecosystem caused by the arboricide treatment. Abrupt alterations in the plant cover will strongly affect the proportions of species in the tree and field layers and the amount and quality of the plant litter. Theoretically, these alterations may also influence the soil fauna, soil microbes, and concentrations of 
mineral nutrients, but such consequences of the MCPA treatment were evidently so slight that they were not clearly demonstrable (Tahvanainen 1980).

One probable explanation of the superior mushroom yield on the sprayed strips in the year following the MCPA treatment may be a temporary increase in dead plant material. In 1978 the amount of tree leaf litter decreased abruptly on the sprayed areas, though the litter originating from the field layer stayed constant (Kasila 1980). Together with the death of the host plants of mycorrhizal fungi, this decrease in tree leaf litter and the resultant reduction in the cycling rate of mineral nutrients may be among the factors responsible for the lowered mushroom yields on the sprayed areas in later years.

Acknowledgements. We are greatly indebted to Jorma Tahvanainen, Dr. Phil., the leader of the project, for arranging facilities for our work and for critical reading of the manuscript, and to Miss Heli Heikkilä, Lic. Phil., for determination of certain species. We also wish to thank Enso-Gutzeit Osakeyhtio for the use of the study area and for the arboricide treatment. The work was supported by the Academy of Finland.

\section{References}

Audus, L.J. (ed.) 1964: The physiology and biochemistry of herbicides. - $555 \mathrm{pp}$. London and New York.

Bollen, W.B. 1961: Interractions between pesticides and soil micro-organisms. - Ann. Rev. Microbiol. 15: 69-92.

Burnett, J.H. 1976: Fundamentals of mycology. - 673 pp. London.
Eronen, L., Julkunen, R. \& Saarelainen, A. 1979: MCPA residues in developing forest ecosystem after aerial spraying. - Bull. Environm. Contam. Toxicol. 21: $791-798$.

Eronen, L., Julkunen-Tiitto, R. \& Saarelainen, R. 1980: MCPA-jäämät lentoruiskutuksen jälkeen puolukassa, sienissä, karikkeessa ja maaperässä. In: Tahvanainen, J. (ed.), Vesankotorjunta-alueiden ekologinen ja ek ofysiologinen tutkimus. Loppuraportti. - Pp. 5-10. Joensuun korkeakoulu.

Gruen, H.E. 1959: Auxins and fungi. - Ann. Rev. Plant Physiol. 10: 405-440.

Kasila, H. 1980: Vesakontorjunnan vaikutuksista kariketuotantoon ja karikkeen hajotukseen nuoressa VTmetsikössä. In: Tahvanainen, J. (ed.), Vesakontorjunta-alueiden ekologinen ja ekofysiologinen tutkimus. Loppuraportti. - Pp. 51-64. Joensuun korkeakoulu.

Lehikoinen, M. 1980: MCPA-ruiskutuksen vaikutuksista kenttä- ja pohjakerroksen kasvillisuuteen. In: Tahvanainen, J. (ed.), Vesakontorjunta-alueiden ekologinen ja ekofysiologinen tutkimus. Loppuraportti. - Pp. 37-50. Joensuun korkeakoulu.

Ohenoja, E. 1978: Mushrooms and mushroom yields in fertilized forests. - Ann. Bot. Fennici 15: 38-46.

Ohenoja, E. \& Takkunen, N. 1974: Alustavia tietoja lannoituksen vaikutuksesta kangasmetsän sienisatoon. (Summary: Preliminary notes on the effect of fertilizers on the mushroom yield of heath forests in Muhos in 1973) - Pyhäkosken Tutkimusaseman Tiedonantoja 10: $1-25$.

Rautavaara, T. 1947: Suomen sienisato. - 534 pp. Forssa.

Salo, K. 1979: Mushrooms and mushroom yield on transitional peatlands in central Finland. - Ann. Bot. Fennici 16: $181-192$

Tahvanainen, J. (ed.) 1980: Vesakontorjunta-alueiden ekologinen ja ek ofysiologinen tutkimus. Loppuraportti. $154 \mathrm{pp}$. Joensuun korkeakoulu.

Veijalainen, H. 1974: Metsäojitusalueiden sienisadosta. (Summary: Mushroom production on drained peatlands.) - Suo 26: $31-33$.

Wilkinson, V.\& I.ucas, R.I.. 1969: Effects of herbicides on the growth of soil fungi. - New Phytol. 68: 709—719.

Accepted for publication

on July 8, 1980 